\title{
Financial Performance, Capital Structure and Share Ownership Structure, Companies Registered on the Indonesia Stock Exchange (Empirical Study on Manufacturing Companies Listed on the Stock Exchange Indonesia Period 2012-2016)
}

\author{
Purwanti and Eddy Irsan Siregar \\ ${ }^{1}$ Pelita Bangsa University \\ ${ }^{2}$ Postgraduate University of Muhammadiyah Jakarta
}

\section{Abstract}

This study will examine Financial Performance, Capital Structure and Structure Share Ownership, Companies that are measured using Economic Value Added (EVA). The sample used in this study uses a method purposive sampling with several

Corresponding Author: Eddy Irsan Siregar siregareddy@gmail.com

Received: 16 September 2019 Accepted: 28 September 2019 Published: 31 October 2019

Publishing services provided by Knowledge E

(c) Purwanti and Eddy Irsan Siregar. This article is distributed under the terms of the Creative Commons Attribution License, which permits unrestricted use and redistribution provided that the original author and source are credited.

Selection and Peer-review under the responsibility of the ICEMA Conference Committee. predetermined criteria. With using the pooled data method, the study sample consisted of 117 observation datalisted on the Indonesia Stock Exchange for the period 2012-2016 obtained from Indonesian Capital Market Directory (ICMD) and also from financial statements annual manufacturing company. The data analysis technique used is regression multiple linear and hypothesis testing using $t$ test and $\mathrm{F}$ test with level $5 \%$ significance. The results of the study indicate that institutional ownership has greater value than managerial share ownership, so that monitoring functions by institutional shareholders are more effective in monitoring. Leverage ratio on manufacturing companies listed at The Indonesia Stock Exchange during the 2012-2016 research period, is still deep the normal range at the lower level is around $30 \%-36 \%$. Asset structure on manufacturing companies listed on the Indonesia Stock Exchange during the period the 2012-2016 research is still quite low, meaning the company's asset structure does not affect the capital structure. The growth of company assets is not affect the capital structure of registered manufacturing companies on the Indonesia Stock Exchange for the period 2012-2016. Capital structure, size the company and the risk of stock returns simultaneously influence on financial performance of manufacturing companies listed on the Stock Exchange Indonesia for the period 2012-2016. Institutional share ownership, ownership managerial shares, company size, risk of stock returns and capital structure the company has an influence on the financial performance of manufacturing companies listed on the Indonesia Stock Exchange during the 2012 study period - 2016

Keywords: Stock Ownership Structure, Capital Structure and Performance Finance Business

\section{G OPEN ACCESS}




\section{Introduction}

The capital market has a big role for the economy of a country, because capital markets carry out two functions at once, namely economic functions and functions finance. Capital markets are said to have economic functions because they provide facilities or vehicles that bring together two interests, namely the party have funds (investors) and parties that need funds (issuers). With the existence of a capital market, the investor can invest the funds in the hope of obtaining returns and issuers (in this case) company) can use these funds for the benefit of activities operational without having to wait for the availability of funds from the company's operations. Market capital is said to have a financial function because the capital market provides possibilities and opportunities to get returns for investors according to the investment characteristics chosen by investors. At the time of the companyutilizing stock funding sources through the market capital (go public) to increase its equity, means providing opportunities to all parties to be able to own company shares. This causes company share ownership is spread across various parties and has an impact on company share ownership structure. Distribution of share ownership structure also has an impact on the motives of the shareholders in their investments. Investor the aim in the short term is to have a gain (profit) or a loss of price difference when the stock is bought and resold in the short term.

\section{Methods and Equipment}

The research method is a scientific way to get data with specific goals and uses (Sugiyono; 2013: 2). This research was conducted at manufacturing companies listed on the Indonesia Stock Exchange during the period research in 2012-2016 using purposive sampling technique from a population of 154 companies with a sample of 117 companies. Data about the tested variables taken from the Indonesian Capital Market Directory and annual financial statements for the period 2012-2016 issued by the company. Purposive sampling is one of the non random sampling sampling techniques where the researcher determines the sampling by specifying special characteristics which is in accordance with the research objectives so that it is expected to answer research problem. Based on the explanation of the purposive sampling, there are two very important thing in using the sampling technique, which is non random sampling and setting special characteristics according to the research objectives by the researcher himself.

The purposive sampling technique steps are as follows: 
1. Determine whether the purpose of the study requires certain criteria for the sample so there is no bias.

2. Determine criteria.

3. Determine the population based on careful preliminary studies.

4. Determine the minimum number of samples that will be used as research subjects as well meet the criteria.

Requirements for Purposive Sampling Techniques include:

1. Criteria or limits are carefully set.

2. Samples taken as research subjects are samples that meet the criteria which have been set.

Strengths of Purposive Sampling techniques:

1. The selected sample is a sample that is suitable for the purpose of the study.

2. This technique is an easy way to do it.

Performance Finance Structure Capital Ownership Stock

3. Selected samples are usually individuals or personal that are easy to find or approached by researchers.

Disadvantages of Purposive Sampling techniques:

1. There is no guarantee that the number of samples used is representative in terms of quantity

2. Not as good as sample random sampling

3. Not including the random sampling method.

4. It cannot be used as a generalization to draw statistical conclusions.

The object of this research generally includes analysis based on aspects share ownership variables and several other exogenous variables (structure assets, asset growth, company size and stock return risk) influence on the capital structure and financial performance of the company, with using agency theory Stock ownership structures and exogenous variables others are exogenousvariables, while capital structure and financial performance company is an endogenous variable. This research is a field research financial management with objects of manufacturing companies listed on the Stock Exchange Indonesia. This type of research is explanatory research conducted for explain the symptoms that arise related to ownership structure share and capital structure of the company's financial performance.

The type of data needed is sourced from the company's financial statements manufacturing listed on the Indonesia Stock Exchange in the period 2012 - 2016. The above 
issues appointed, with a view to knowing the structure of share ownership (Institution and Managerial) and other exogenous variables (asset structure, asset growth, company size and stock return risk in influencing capital structure and company financial performance. Observations were made on the population that was the sample of the study, all of them companies that are active and provide financial reports in the period 20122016 at Indonesia stock exchange. This period was chosen because of the economic conditions in the situation relatively normal after recovering from the economic crisis in 2008 that occurred as an impact of the subprime mortgage crisis in the United States, where credit housing in the US is given to debtors who have a credit portfolio which is not good. Based on the static data from ICMD it is known that the number manufacturing companies listed on the Indonesia Stock Exchange up to year 2016 is 154 companies. In this study, companies will studied are manufacturing companies listed on the Indonesia Stock Exchange period year 2012- 2016. From these criteria, there are 117 companies meeting the next criteria will be used as a sample in this study Some indicators are taken into consideration during the research period among others are:

1. The condition of Indonesia's economic growth after the crisis in 2008, at good first quarter of 2012 (Indonesia Economi Quarterly for March 2012).

2. Growth in the fourth quarter of 2011 exceeded expectations and above the last 10 years.

3. The World Bank raises Indonesia's economic growth estimates for the year 2011 to 6.4 percent with a further increase of 6.7 percent in 2013.

4. Balance of payments remains strong, and foreign investment has increased. This research was conducted to find out and analyze the influence of share ownership, capital structure and corporate financial performance with the object of research are manufacturing companies listed on the Stock Exchange Indonesia. This research was conducted to find out whether the agency theory can be implemented as a basis in applying share ownership and structure capital in the company, in order to improve the company's financial performance in particular manufacturing companies listed on the Indonesia Stock Exchange during the study periodyear 2012-2016.

Based on the purpose of social research can be divided into several kinds, namely explorative, descriptive, explanatory, verification and research development. This study aims to find out which theories apply to the application of theory capital structure of manufacturing companies in Indonesia, based on that this research is grouped into verification research. Verification research is a research that aims to test a theory or the results of previous research, to obtain results that strengthen or abort a theory or previous results. According to Arikunto (2004) verification research basically wants 
to test the truth through gathering data. The nature of verification basically wants to test the truth of a hypothesis implemented through data collection. Apart from being classified into verification research, this research is also included descriptive research. Descriptive Statistics is the statistics used to analyze data by describing or describing data which has been collected as it is, without intending to draw conclusions that applies to general or generalization

\subsection{Variable Operationalization}

Based on the framework, premise, and hypothesis proposed; variable used in this study are:

\subsubsection{Exogenous Variable}

\section{Shareholding}

Independent Variables in this study are Share Ownership consisting of institutional ownership, managerial share ownership, corporate asset structure, growth in company assets, company size and risk of stock returns

a. Institutional Share Ownership (KI) This variable represents the percentage of share ownership held by the institution as a monitoring agent caused by the size of their investment in the market capital (Wahidahwati, 2001; Brailsford, Oliver, and Pua, 2002). This variable can seen from the value of the proportion of ordinary shares held by the institution (company, fund pension, insurance, bank) for the total outstanding ordinary shares for 5 (five) years.

b. Managerial Share Ownership (KM) This variable is the percentage of share ownership held by the party management who actively participates in corporate decision making (Bathala Moon, Rao, 1994; Wahidawati, 2001). The management consists of directors and commissioner. Data is taken for 5 (five) years.

c. Asset Structure (SA) This variable reflects the value of company assets that can be used as collateral for obtaining loans from bondholders (Titman and Wessels, 1988; Wahidawati, 2001) which is measured using the ratio of fixed assets to total assets for 5 (five) years.

d. Asset Growth) This variable reflects the growth of resources in the form of assets and owned by the company, measured by the difference in total asset value between the end with the beginning of the year divided by the total asset value at the beginning 
of the year (Titman and Wessels, 1988; Brailsford, Oliver, and Pua, 2002). This data is calculated for 5 (five) years.

e. Company Size This variable shows the size of the company over a certain period, which is can be seen from sales (Lauterbach and Vaninsky, 1999). This variable is measured by using a natural log of the annual sales value of 5 (five) year.

f. Risk of Stock Returns This variable reflects the variability of corporate income and is defined as coefficient of profit variation (Lauterbach and Vaninsky, 1999). This variable is measured by use the standard deviation of changes in monthly stock prices for 5 (five) years.

\subsubsection{Capital Structure}

This variable is used to see the composition between debt and equity company (Weston and Copeland, 1992). This variable is measured in a way compare the value of the book value ratio of long-term debt to market value equity plus long-term debt for 5 (five) years.

\subsection{Endogenous variable}

\subsubsection{Corporate Financial Performance}

This variable is a measure of the results of a process carried out in internal company for a certain period. The measure of company performance is calculated use EVA in proportions (Stewart, 1991), which is obtained through dividing NOPAT against Capital is reduced by WACC for 5 (five) years.

\section{Results}

1. It was found that the level of institutional share ownership in the company manufacturing listed on the Indonesia Stock Exchange in the period 2011-2015 has greater value than managerial share ownership, so that monitoring functions by institutional shareholders are more effective in monitoring the opportunistic behavior of management and discipline the use of debt in carrying out its activities, conditions this can eliminate the defense effect from the management. 
2. The results of the study found that managerial share ownership is low, so that management from the institution is more dominant, so monitoring internal becomes weaker.

3. Leverage ratio in manufacturing companies listed on the Stock Exchange Indonesia during the 2012-2016 study period, still within the range normal at the level below 50 percent which is around 34 percent - 36 percent. Average low leverage ratio indicates that the source the company's funding in the long term is dominantly sourced from equity and company activities tend to be financed from their own capital.

4. The results of the empirical findings from this study show supporting results (consistent) with previous research such as:

a. Institutional share ownership of the company's capital structure positive effect, this study isconsistent with the results of the study carried out by Bathala, Moon, Rao (1994) and Dhani (2003).

b. Asset structure has a positive effect on the company's capital structure, this is consistent with the results of research conducted by Titman and Wessels (1988), Brigham and Gapensi (1996), Wald (1999), and Wahidahwati (2001).

c. Asset Structure growth has a negative effect on capital structure company, this is consistent with the results of research conducted by Titman and Wessels (1988) and Pecking Order theory.

d. Institutional Share Ownership has a positive effect on performance company finance, this is consistent with the results of the research carried out by Bathala, Moon, Rao (1994); Kuznetsov and Muravvey (2001), Berger and Patti (2002).

e. Managerial Share Ownership has a positive effect on performance company finance, this is consistent with the research conducted by Jensen and Meckling (1976).

f. Company size has a positive effect on financial performance company, this is consistent with the research conducted byBarton, Hill and Sundara (1989), Chang and Rhee (1990) and Lauterbach and Vaninsky (1999).

5. Research results that are opposite (inconsistent) with research before is

a. Managerial Share Ownership has a positive effect on structure capital, this result is not consistent with the research conducted by Jensen and Meckling (1976), This means an alignment role between shareholders with management not functioning.

b. Capital structure negatively influences the company's financial performance, this result inconsistent with the theory of Trade Off. This means a decision funding by companies does not follow the rules of capital structure theory optimum. 


\section{Discussion}

\subsection{Pool Model Test}

The pool model test is done to determine the type of model used whether the panel model or common / pool model (Baltagi, 2008). This test I early detection whether panel data to be processed must be estimated using a panel the model or common / ool model tested using the Chow test and the results as follows.

TABle 1: Chow Test Results To Test the Common / Pool Model or Panel Model.

\begin{tabular}{|l|c|c|c|}
\hline Model & FStatistic & probability & Conclusions \\
\hline Capital Sturcture & 21,327 & $<0,001$ & Panel model \\
\hline Performances of Firms & 5,360 & $<0,001$ & Panel model \\
\hline Source: Data Results (2018) & & & \\
\hline
\end{tabular}

The results of the pool model test show that the model panel is the right choice is used in estimating the capital structure model and model company financial performance. This is indicated by the results of the Chow test significant at level 5 percent (probability value $<0.05$ ). Because the conclusions from Chow test is a model panel, it is necessary to continue testing the model specifications.

\subsection{Test Model Specifications}

Test the model specifications to determine the type of model used in estimation whether random effect or fixed effect (Gujarati \& Porter, 2009: 603).

This test is needed because the data to be processed is panel data, i.e. Combined cross section data with time series data. Model specification tests are carried out use the Hausman test and the results are as follows.

TABLE 2: Hausman Test Results To Determine a Fixed Model or Random Model (Source: Data Results).

\begin{tabular}{|l|c|c|c|}
\hline Model & FStatistic & probability & Conclusions \\
\hline Capital Structure & 14,70 & 0,005 & fixed effect \\
\hline Performances of Firm & 17,20 & 0,004 & fixed effect \\
\hline Source: Data Results & & & \\
\hline
\end{tabular}

The Hausman test results show that the FX effect is the right choice for estimating the capital structure model and the company's financial performance model, this is indicated by the Hausman test results which are significant at the $5 \%$ level (probability 
value $<0.05)$. Because the Chow test test results are the most appropriate panel model used in estimating the regression equation, then the next is not necessary to test the classic assumptions such as normality test, autocorrelation test and heteroscedasticity test. As stated by Gujarati \& Porter (2009; 447): "whenever we use an FGLS or EGLS, the estimated coefficients will not have the usual optimum properties of the classical model, such as BLUE "

\subsection{Multicollinearity Test}

Multicollinearity means that there is a strong relationship between several or all independent variables in the regression model. If there is Multicollinearity then the regression coefficient becomes uncertain, the error rate becomes very large and is usually marked by a very large coefficient of determination but in partial testing the regression coefficient, none or if there are very few significant regression coefficients. In this study used the value of variance inflation factors (VIF) as an indicator of the presence or absence of multicollinearity between independent variables. If the VIF value is still smaller than 10 , there are no symptoms of multicollinearity (Gujarati, 2009: 432). The following presents the VIF values of each independent variable in each model.

TABLE 3: Test Results for Multicollinearity Assumptions.

\begin{tabular}{|l|c|c|c|c|c|}
\multicolumn{3}{c}{ Capital Structure Model } & \multicolumn{3}{c|}{ Financial Performance Firms Model } \\
\hline Variabel & R- square & VI F & Variabel & R- square & VIF \\
\hline KI & 0,146 & 1,17 & SMF & 0,060 & 1,06 \\
\hline KM & 0,073 & 1,08 & KI & 0,129 & 1,15 \\
\hline SAP & 0,863 & 7,29 & KM & 0,100 & 1,11 \\
\hline PAP & 0,859 & 7,08 & UP & 0,051 & 1,05 \\
\hline & & & RRS & 0,005 & 1,01 \\
\hline
\end{tabular}

Through the VIF values obtained as presented in table 4.20 above, it shows that there is no strong correlation between the variables independent. This is indicated by the VIF value of the independent variable is still smaller than 10 so it can be concluded that there are no symptoms of multicollinearity between the independent variables, both in the capital structure model and in the company performance model.

Capital Structure Regression Analysis The first model to be tested is the influence of independent variables namely managerial ownership, institutional ownership, the 
structure of the company's assets and the growth of the company's assets on the capital structure. The estimation of this multiple linear regression model uses fixed effects.

TABLE 4: Results of Capital Structure Regression Analysis.

\begin{tabular}{|c|c|c|c|c|}
\hline \multicolumn{5}{|c|}{ Method: Panel EGLS (Cross-section weights) Date: 11/26/17 Time: 06:55 } \\
\hline \multicolumn{5}{|l|}{ Sample: 20112015} \\
\hline \multicolumn{5}{|l|}{ Periods included: 5} \\
\hline \multicolumn{5}{|c|}{ Cross-sections included: 117} \\
\hline \multicolumn{5}{|c|}{ Total panel (balanced) observations: 585} \\
\hline \multicolumn{5}{|c|}{ Linear estimation after one-step weighting matrix } \\
\hline \multicolumn{5}{|c|}{ Cross-section weights (PCSE) standard errors \& covariance (d.f. corrected) } \\
\hline Variable & Coefficient & Std. Error & t-Statistic & Prob. \\
\hline C & 0.153452 & 0.007437 & 20.63269 & 0.0000 \\
\hline $\mathrm{KI}$ & -0.003310 & 0.010955 & -0.302198 & 0.7626 \\
\hline KM & -0.112180 & 0.046588 & -2.407918 & 0.0164 \\
\hline SAP & -0.012185 & 0.007075 & -1.722219 & 0.0857 \\
\hline PAP & 0.010204 & 0.007040 & 1.449457 & 0.1479 \\
\hline \multicolumn{5}{|c|}{ Effects Specification } \\
\hline \multicolumn{5}{|c|}{ Cross-section fixed (dummy variables) } \\
\hline \multicolumn{5}{|c|}{ Weighted Statistics } \\
\hline R-squared & 0.966323 & Mean dependent var & 0.30496 & 1 \\
\hline Adjusted R-squared & 0.957614 & S.D. dependent var & 0.22112 & 1 \\
\hline S.E. of regression & 0.064057 & Sum squared resid & 1.90391 & 3 \\
\hline F-statistic & 110.9508 & Durbin-Watson stat & 1.99794 & 2 \\
\hline Prob(F-statistic) & 0.000000 & & & \\
\hline \multicolumn{5}{|c|}{ Unweighted Statistics } \\
\hline R-squared & 0.857426 & Mean dependent var & 0.14702 & 6 \\
\hline Sum squared resid & 1.986278 & Durbin-Watson stat & 1.77287 & 6 \\
\hline
\end{tabular}

Through the results obtained as shown in the table above, multiple linear regression equations can be formed as follows:

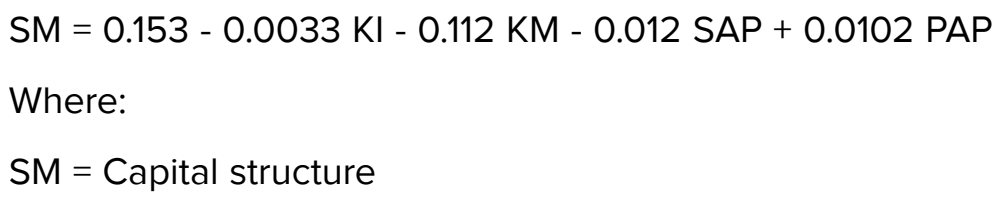


$\mathrm{KI}=$ Institutional ownership $\mathrm{KM}=\mathrm{SAP}$ managerial ownership = Company asset struc ture

PAP = Company asset growth

The constant value of 0.153 shows the average ratio of long-term debt to the total assets of manufacturing companies on the Indonesia Stock Exchange when all independent variables are zero. Institutional ownership has a negative coefficient of 0.0033 , meaning that every increase in institutional ownership by 1 percent is expected to reduce the capital structure by 0.0033 percent. Then managerial ownership has a negative coefficient of 0.112 , meaning that every increase in managerial ownership by 1 percent is expected to reduce the capital structure by 0.112 percent.

The asset structure of the company has a negative coefficient of 0.012 , meaning that every increase in the ratio of fixed assets to total assets of 1 percent is expected to reduce the capital structure by 0.012 percent. Finally, a company's asset growth has a positive coefficient of 0.0102 , meaning that every growth in fixed assets of 1 percent is expected to increase the capital structure by 0.0103 percent.

\subsection{Testing the Direction of Coefficients}

Testing the direction of the coefficient is done to find out whether the direction of the coefficient of the research results is in accordance with the proposed hypothesis or not. Testing the direction of the coefficient is done by comparing the direction of the coefficient of the research results with the hypothesis. The results of testing the direction of the coefficient, appear in the table below.

Most of the research variables have the correct (consistent) direction as the hypothesis proposed, except for the direction of the relationship between the Company Asset Structure variable and Company Asset Growth that is contrary to the hypothesis.

\subsubsection{Determination Coefficient Testing}

The coefficient of determination is calculated to determine how much influence the independent variables (managerial ownership, institutional ownership, corporate asset structure and growth of company assets) simultaneously on the capital structure. Based on the results of data processing using the Eviews software found in the table above, the adjusted R-Square value is 0.958 or 95.8 percent. This means that managerial ownership, institutional ownership, corporate asset structure and company asset growth simultaneously contribute or influence $95.8 \%$ of the capital structure of manufacturing 
TABLE 5: Testing the Direction of Coefficients.

\begin{tabular}{|c|c|c|c|}
\hline Variabel & Hipotesis & Coefficient Model & Conclusions \\
\hline \multicolumn{4}{|c|}{ (Capital Structure Model) Test } \\
\hline KI & - & - & $\begin{array}{l}\text { The direction of influence is consistent with Hipothesis } \\
\text { hypothesis }\end{array}$ \\
\hline KM & - & - & The direction of influence is consistent with Hipothesis \\
\hline SAP & - & - & The direction of influence is consistent with Hipothesis \\
\hline PAP & + & + & The direction of influence is consistent with Hipothesis \\
\hline \multicolumn{4}{|c|}{ Financial Performance Firms Model Test } \\
\hline KI & + & + & The direction of influence is consistent with Hipothesis \\
\hline KM & - & - & The direction of influence is consistent with Hipothesis \\
\hline$S M$ & +1 & - & The direction of influence is consistent with Hipothesis \\
\hline RRS & - & - & The direction of influence is consistent with Hipothesis \\
\hline LnUP & + & + & The direction of influence is consistent with Hipothesis \\
\hline
\end{tabular}

companies in the Indonesia Stock Exchange. The remaining influence of other factors not examined is 4.2 percent, which is the influence of other factors beyond managerial ownership, institutional ownership, corporate asset structure and the growth of company assets.

Furthermore, to test the significance of the influence of managerial ownership, institutional ownership, corporate asset structure and the growth of company assets on the capital structure, both hypothesis testing and partial testing are done simultaneously. The test starts from a simultaneous test and is followed by a partial test.

\section{Simultaneous Testing}

Simultaneous testing aims to prove whether managerial ownership, institutional ownership, corporate asset structure and growth of company assets simultaneously influence the capital structure with the formulation of the statistical hypothesis as follows:

Ho: All i = O Managerial ownership, institutional ownership, corporate asset structure and simultaneous growth of company assets have no effect manufacturing company on the Indonesia Stock Exchange

Ho: There is $\mathrm{i}=0$ Managerial ownership, institutional ownership, corporate asset structure and company asset growth simultaneously influence the capital structure of manufacturing companies in the Indonesia Stock Exchange 
A summary of the test results used to examine the effect of managerial ownership, institutional ownership, corporate asset structure and the simultaneous growth of company assets on capital structure can be seen in the following table.

TABLE 6: Simultaneous Influence Test Results on Capital Structure.

\begin{tabular}{l|c|c|c|c|}
$\begin{array}{l}\text { Coefficient } \\
\text { Determinant }\end{array}$ & Fstatistic & Probability & Ftable (121\&463) & Ho \\
\hline 0,958 & 110,95 & $<0,001$ & 1,26 & Rejected \\
\hline Source: Data Outcomes (2018). & & & \\
\hline
\end{tabular}

In table 4.6, it can be seen that the Fstatistic value of the data processing is 110.95 with a probability value close to zero. Because Fstatistic is greater than Ftable, the error rate of 5 percent $(=0.05)$ is decided to reject Ho so that $\mathrm{Ha}$ is accepted. Thus it can be concluded that managerial ownership, institutional ownership, corporate asset structure and growth of company assets simultaneously influence the capital structure of manufacturing companies in the Indonesia Stock Exchange.

\section{Partial Testing}

Partial testing will examine the effect of each independent variable on the dependent variable. The test statistic used in the partial test is the t test, where the table value is used as a critical value in the partial test ( $t$ test) of 1.97 obtained from the tab for two-way testing. The value of $t$ test statistics used in the test partially can be seen in table 4.22. The test criteria used are as follows.

If $\mathrm{t}$ count $>\mathrm{t}$ table, or $\mathrm{t}$ count $<$-ttable then $\mathrm{HO}$ is rejected (significant) If -ttable $\leq \mathrm{t}$ count $\leq$ ttable, then $\mathrm{HO}$ is accepted (not significant).

\section{Conclusion}

1. It was found that the level of institutional share ownership in manufacturing companies listed on the Indonesia Stock Exchange for the period 2012-2016 has greater value than the monitoring function by institutional shareholders is more effective in monitoring the opportunistic behavior of management and disciplining the use of debt in carrying out its activities, this condition can eliminate the defense effect from the management.

2. The results of the study found that managerial share ownership was low, so management from the institution was more dominant, so internal monitoring was weaker. 
3. The leverage ratio for manufacturing companies listed on the Indonesia Stock Exchange during the 2012-2016 study period is still in the normal range at levels below 50 percent, which is around 34 percent - 36 percent. The average low leverage ratio indicates that the company's funding source in the long run is dominantly sourced from equity and company activities tend to be financed from their own capital.

4. The empirical findings from this study show results that are supportive (consistent) with previous studies such as:

a. Institutional share ownership of the company's capital structure has a positive effect, this study is consistent with the results of research conducted by Bathala, Moon, Rao (1994) and Dhani (2003).

b. Asset structure has a positive effect on the company's capital structure, this is consistent with the results of research conducted by Titman and Wessels (1988), Brigham and Gapensi (1996), Wald (1999), and Wahidahwati (2001).

c. Asset Structure growth has a negative effect on the company's capital structure, this is consistent with the results of research conducted by Titman and Wessels (1988) and Pecking Order theory.

d. Institutional Share Ownership has a positive effect on the company's financial performance, this is consistent with the results of research conducted by Bathala, Moon, Rao (1994); Kuznetsov and Muravvey (2001), Berger and Patti (2002).

e. Managerial Share Ownership has a positive effect on the company's financial performance, this is consistent with the research conducted by Jensen and Meckling (1976).

f. Company size has a positive effect on the company's financial performance, this is consistent with research conducted by Barton, Hill and Sundara (1989), Chang and Rhee (1990) and Lauterbach and Vaninsky (1999).

5. Research results that are opposite (inconsistent) with previous research are

a. Managerial Share Ownership has a positive effect on capital structure, this result is not consistent with the research conducted by Jensen and Meckling (1976). This means that the alignment role between shareholders and management does not function.

b. Capital structure negatively influences the company's financial performance, this result is not consistent with the theory of Trade Off. This means that funding decisions by companies do not follow the rules of optimum capital structure theory. 


\section{References}

[1] Abbasi, Majid., Kalantari, Elham., And Hamideh. (2012). Impact of Corporate Governance Mechanism on Firm Value: Evidance from the Food Industry in Iran, Journal of Basic and Applied Scientific Research, 2 (5): 4712-4721.

[2] Agnes Sawir, (2003) Financial Performance Analysis and Corporate Financial Planning, Jakarta: Gramedia Main Library.

[3] Andrew C. Worthington and Tracey West, (2004), Australian Evidence Concern the Information Content of Economic Value-Added, Australian Journal of Management 29 (2): pp. 201-224

[4] Akerlof, G. (1970). The market for lemons: Quality uncertainty and the market mechanism. The Quarterly Journal of Economics, 89: 488-500

[5] Ang, James S., Cole, Rebel A, and Lin, James Wuh, (2000), Agency Cost and Ownership Structure, The Journal of Finance (February) Vol LV, no. 1, page 81-106

[6] Anil K. Sharma and Satish Kumar, (2010), Economic Value Added (EVA) - Literature Review and Relevant Issues, International Journal of Economics and Finance.

[7] Ang, James; Cole, Rebel; Lawson, Daniel, (2003), The Role of Owner in Capital Structure Decisions: An Analysis of Single-Owner Corporations

[8] Ananth Sailoganathan, John Siderov, Ebi Osuobeni, (2008) A new Gujarati language log MAR visual acuity chart: Development and validation, p.1-6

[9] Aydin Ozkan, (2001) Determinants of Capital Structure and Adjustment to Long Run Target: Evidence From UK Company Data Panel, Volume 28, Issue 1-2 January / March 2001 p. 175-198

[10] Bathala, Chenchuramaiah T, Kenneth P Moon, and Ramesh P. Rao,(1994) Managerial Ownership of Debt Policy and the Impact of Institutional Holdings: An Agency Perspective, Journal of Finance Management (Authum) Vol 2319943 page 38-50

[11] Bayrakdaroglu, Ali., Ersoy, Ersan, and Citak, Levent. (2012). Is there A Relationship Bet ween ISSN Corporate Governance and Value-Based Financial Performance: 23028556 Accounting E-Journal of Udayana University. 9.1 (2014): 58-68 Measures? A Study of Turkey as An Emerging Market. Asia Pacific Journal of Financial Studies 41, 224-239.

[12] Berger, P.G, E. Ofek, and D.L. Yermack. (1997). Managerial Entrepreneurship and Capital Structure Decisions. Journal of Finance. Vol. 52, p. 1411-1438.

[13] Bodie, Kane Alex, Marcus Alan. (2006). Investment, Interpreting by Zuliani Dalimunthe and Budi Wibowo. Jakarta: Salemba Empat. 
[14] Boursli, Amani Khaled. (2001). Managerial Incentives and Firm Performance: Evidance from Initial Public Offering. Dissertation, The Southern Illinois University Graduate School. Brailsford, Oliver and Pua,(2002) On the Relations Between Ownership Structure and capital structure, Journal of Accounting and finance No. 42 page $1-26$,

[15] Brigham, E. F., Gapenski, L. (1996), Intermediate Financial Management Fifth, Edition. New York: The Dryden Press.

[16] Brigham, Eugene F, Ehrhardt, Micahel C, (2005), Financial Management, Theory and Practice, 11th Edition, Southwestern Cengage Learning, USA

[17] Calisir, Fethi, Cigdem Altin Gumussoy, A Elvan Bayraktaroglu, and Ece Denis. (2010). "Intellectual Capital in the Quoted Turkish ITC Sector". Journal of Intellectual Capital, Vol. II (4), page 537-553.

[18] Chen., et all, (2009), How the Pecking-Order Theory Explain Capital Structure

[19] Chkir, Imed, (2004) Diversification et structure du capital des entreprises multinationales un model de changement de regime, Finance: Revue de l'Association Française de Finance; June 2004; 25, 1; ABI / INFORM Complete page 31)

[20] Chowdhury Sanjida, Hossain Mahbub and Miah Tofazzal H, (2013), Role of SL8H super hybrid rice to achieve food security in Bangladesh: Interpretations of survey results, International Journal of Agricultural Policy and Research Vol.1 (3), pp.053061

[21] Copeland, Thomas E.,; Weston J. Fred, (1946), Financial Theory and Corporate Policy, Addison-Wesley Publishing Company, Library of Congress Cataloging-in-Publication Data.

[22] Cortez Michael Angelo., Susanto Stevie, (2012), Corporate Capital Structure: Evidence From Japanese Manufacturing Companies, Journal of International Business Research, Volume 11, Special Issue, Number 3. 2012

[23] Cueto, Diego C, Market Liquidity and Ownership Structure with Weak Protection for Minority Shareholders: Evidence, from Brazil and Chile, Universidad ESAN

[24] Damsetz, H and K. Lehn. (1985). The Structure of Corporate Ownership: Causes And Consequences. Journal of Political Economy. 93. Page 1155-1177.

[25] Easterbrook, F.H., (1984), Two Agency Cost Explanation of Dividends, American Economic Review 74, 650-659.

[26] Erdinc Karadeniz, Serkan Yilmaz Kandır, Ömer Iskenderoğlu, Yıldırım Beyazit Onal, (2011) Firm Size And Capital Structure Decisions: Evident 